\title{
Developing Deprivation Index for Leeds Using Housing Conditions and Demographic Profiling
}

\author{
Najla Al-Thani \\ Independent Scholars, Leeds, UK \\ Email: andersonfaye7@gmail.com
}

How to cite this paper: Al-Thani, N. (2016) Developing Deprivation Index for Leeds Using Housing Conditions and Demographic Profiling. Open Journal of Social Sciences, 4, 45-55.

http://dx.doi.org/10.4236/jss.2016.49006

Received: August 11, 2016

Accepted: September 18, 2016

Published: September 21, 2016

Copyright $\odot 2016$ by author and Scientific Research Publishing Inc. This work is licensed under the Creative Commons Attribution International License (CC BY 4.0).

http://creativecommons.org/licenses/by/4.0/ (c) (i) Open Access

\begin{abstract}
Poverty has been significant to the community of the United Kingdom to the extent of being almost every government's promise to combat it. The large overlap between poverty and deprivation allows us to study the latter as a proxy of the former. This study investigates deprivation in England and Wales in general and the city of Leeds in particular, by focusing on housing conditions indicator (HPC). The analyses conducted included pair-wise associations, multivariate linear regressions and formulating a deprivation index using standardised value. For England and Wales, housing in poor condition indicator was strongly associated with population size, percentage of job seekers, percentage of users of incapacity benefits, percentage of lone parent, percentage of disabled, percentage of females, Combined Living Environment Indicator (CLEI) and levels of air pollutants; whereas for Leeds, HPC was significantly associated with percentage of lone parent and CLEI. The geographic distribution of Leeds deprivation index was similar to those developed for Leeds but present more deprived areas at the peripheries of the city. Moreover, the analyses showed that gender or age distribution of the population did not play a significant role to housing deprivation in Leeds. Although the results of this study agree greatly with previous relevant research, the outcomes pose questions for future research especially the need to investigate the deprivation at the edges of the city away from the historically deprived central areas. Finally, the findings of this study call for social and environmental policy makers to regulate housing near highly polluted areas.
\end{abstract}

\section{Keywords}

Leeds, Poverty, Deprivation, Poor Housing, Lone Parent

\section{Introduction}

Population poverty has been the interest of social research. According to Peter Townsend, "individuals, families and groups in the population can be said to be in poverty 
when they lack the resources to obtain the types of diet, participate in the activities, and have the living conditions and amenities which are customary, or at least widely encouraged or approved, in the societies to which they belong. Their resources are so seriously below those commanded by the average individual or family that they are, in effect, excluded from ordinary patterns, customs and activities" [1]. This relative deprivation approach of poverty includes among other things, access to proper diet, clothing, transportation, housing, recreation health and education. Hence, measures of access to these resources can be used individually or combined to quantify deprivation [2].

Therefore, population deprivation cannot be separated from housing because of its direct connection to income and provision for living conditions. This has driven a plethora of research which documents this interaction and its implications. Although poverty can be defined from different perspectives like relative poverty, European Commission definition, relative income poverty and absolute poverty, all of these inherently point to housing as an indicator and an outcome of poverty [3]. On the other hand, housing affects poverty by providing disposable income through high value housing (low cost and good quality). Poor housing conditions affect child development and adult health. Such relationships are complicated and multi-faceted, which makes them difficult to prove. The relationship between housing and poverty is important and needs more attention from social policy in order to have suitable measures to limit housing costs especially rent in privately owned properties. Moreover, housing conditions need to be monitored and Housing Benefits need to be adjusted accordingly. Such measures are affected by confounding factors like employment and disability [4].

The purpose of this study was to investigate the factors that contribute to poor housing conditions like employment, household head (single parent), disability, gender and air quality of the housing location, for England and Wales in general and for Leeds in particular. All of these factors can be indicators of income and thus poverty level. The significance of exploring such associations lie in directing the attention of social policy makers and the public to the complex associations and thus find ways to level the disparities in the community.

Leeds is one of the most important British cities not only because of its rich history but for its current socioeconomic potential. Leeds "spawned the current three most successful high street chains in the UK", home to the oldest working railway in Britain-Middleton Railway, home of the world's first disco and indoor leagues, giving the world the mouse trap, paved the way for DNA discovery plus other pioneering achievements nationally and globally. With a about half million population, few of the top schools and universities, active cultural and shopping centres and a diverse community, Leeds presents a unique example other cities [5] [6] and this is the rationale for its selection. Finally, contrasting Leeds against England and Wales puts things in perspective because after all it is an English city.

\section{Methods}

\subsection{Data and Statistical Calculations}

Data was extracted from one of the data repositories by the national statistics agencies 
in the UK the ONS Neighbourhood Statistics (NeSS) website found at http://www.neighbourhood.statistics.gov.uk/ [7]. The three administrative datasets downloaded are titled "Indices of Deprivation 2007 Underlying Indicators: Living Environment", "Benefits Data: Working Age Client Group" and "Indices of Deprivation 2007 Underlying Indicators: Employment", for England and Wales in 2007. These three datasets were linked using the LSOA code field.

Other than the Lower Layer Super Output Area (LSOA) geographic variables, the eighteen variables of interest for this multivariate analysis are: Total Persons, Percentage Job Seekers (js), Percentage Incapacity Benefits (ib), Percentage Lone Parent (lp), Percentage Disabled (d), Percentage Male (male), Percentage Female (female), Percentage Aged 16 - 24 (p1624), Percentage Aged 25 - 49 (p2549), Percentage Aged 50 and Over (p50), Combined Employment Indicator (CEI), Combined Living Environment Indicator (CLEI), Housing In Poor Condition indicator (HPC), Combined Air Quality Indicator (AQI), ratio of nitrogen dioxide $\left(\mathrm{NO}_{2}\right)$, ratio of particulates (PM10), ratio of sulphur dioxide $\left(\mathrm{SO}_{2}\right)$, ratio of benzene $\left(\mathrm{C}_{6} \mathrm{H}_{6}\right)$. The map for LSOA was downloaded from data.gov.uk website [8]. The number of records extracted was 32,482. Although AQI usually suffices as an indicator of air quality, having the individual air pollutants can help identify the main source of air pollution as to whether it is industrial or from traffic pollution [9]. The Employment indicator combines two sub-indicators: a) Illness and b) Unemployment Benefits and New Deal, whereas HPC pools "two sub-indicators on the 'indoors' living environment: a) Housing in Poor Condition, b) Central Heating, and two sub-indicators on the 'outdoors' living environment: c) Road Traffic Accidents and d) Air Quality indicator combining i) Nitrogen Dioxide, ii) Particulates (PM10), iii) Sulphur Dioxide, iv) Benzene" [7]. CLEI is mutually exclusive with HPC [7].

The variables were tested for multivariate normality using Shapiro-Wilk normality test, Pearson pair-wise correlations were calculated, univariate linear regressions were conducted and only significant predictors were used to conduct the multivariate linear regression with HPC or failing to meet the Decent Homes Standards as being the dependent variable. The last step of the analysis was to create an index for Leeds LSOA's population deprivation using the most significant predictors (independent variables) by adding their standardized values then plotting them geographically.

\subsection{Software}

ArcMap version 10.3.1 [10], R version 3.1.1 [11] and Microsoft Excel were used to manage and analyse the data, Microsoft Word was used to create this report and EndNote X7 was used to manage the references following the Leeds University Harvard referencing style.

\section{Results}

\subsection{England and Wales}

The combined (merged) dataset contained 32,482 records. Descriptive statistics for the 
main fourteen variables are presented in Table 1 . Variability was not too large except for total persons (standard deviation $=88.86$ ) or LSOA population. All percentages ranged from zero to one hundred except for percentage of job seekers $(0 \%-67 \%)$ and percentage of households with lone parent $(0 \%-53 \%)$. Normality test confirmed normality of the variables. Hence, no transformation was required.

\subsection{Leeds}

The Pearson pair-wise correlations are presented in Table 2 and the Pearson pair-wise associations for air quality index and pollutants are presented in Table 3. Table 4 summarizes the unadjusted bivariate linear regressions and Figure 1 presents the constructed linear regression formula for HPC which explains 88.1 percent of variation within the dataset. Regression coefficients with their p-values are presented in Table 5. The number of LSOAs for Leeds was 476. Table 6 presents summary statistics for the explored variables. Most of the variables' values were similar to those for England and Wales (Table 1). However, Leeds had one percent less lone parents, one percent less disabled, two and a half percent more job seekers, one percent more males, two percent less females and one percent more aged 16 - 15 years. Pearson pair-wise correlations that were statistically significant are presented in Table 7. Compared to those of England and Wales (Table 2), it is interesting to find that HPC's correlation to percentage of job seekers in Leeds was 0.47 whereas it was 0.27 in England and Wales. Also, HPC's correlation to CLEI in Leeds was 0.95 but 0.86 in England and Wales. The rest of pair-wise correlations were similar. Pearson pair-wise associations for air quality index and pollutants for Leeds were not too different from those of England and Wales. Figure 2 presents HPC values for Leeds LSOA. Unadjusted bivariate linear regressions on HPC for Leeds were similar to those of England and Wales but the adjusted R-square values were slightly higher by about ten percent. Repeating the same approach to the LSOAs of Leeds, only four variables were statistically significant (p-value less than the significance level of 0.05): percentage of job seekers, percentages of lone parent, combined employment indicator and CLEI. Figure 3 presents the linear formula for the regression which had an adjusted R-square high value of 90 percent. Analysing residuals carefully (Figure 4(a) and Figure 4(b)) shows their normality and symmetry which validates the assumptions of the model and that the linear formula (Figure 3 ) is an appropriate model for Leeds LSOA HPC [12] [13].

Based on the above results, percentage of lone parent and CLEI were standardised and added together to form Leeds deprivation index. Figure 5 presents the geographic distribution of the developed index. The intensity of the index is very similar to HPC's (Figure 2) and to other deprivation indices developed in other studies [14], but with slight differences at the LSOAs at the periphery of the City. The developed index shows higher deprivation at the margins of the city.

\section{Discussion}

This study investigates the factors associated with poor housing in both Leeds and 
Table 1. Summary statistics for England and Wales.

\begin{tabular}{|c|c|c|c|c|c|c|c|c|}
\hline & Mean & Median & Mode & Std. Dev. & Kurtosis & Skewness & Minimum & Maximum \\
\hline Total Persons & 135.85 & 110.00 & 65.00 & 88.86 & 2.11 & 1.32 & 0.00 & 880.00 \\
\hline Percentage Incapacity Benefits & 49.18 & 50.00 & 50.00 & 9.44 & 0.40 & 0.06 & 0.00 & 100.00 \\
\hline Percentage Disabled & 7.79 & 7.00 & 6.00 & 5.13 & 6.36 & 1.39 & 0.00 & 100.00 \\
\hline Percentage Male & 48.99 & 50.00 & 50.00 & 7.72 & 1.37 & -0.04 & 0.00 & 100.00 \\
\hline Percentage Female & 51.03 & 50.00 & 50.00 & 7.72 & 1.38 & 0.02 & 0.00 & 100.00 \\
\hline Percentage Aged 50 and Over & 37.11 & 36.00 & 50.00 & 11.02 & -0.14 & 0.39 & 0.00 & 100.00 \\
\hline Employment Indicator & 0.10 & 0.08 & 0.05 & 0.07 & 2.53 & 1.44 & 0.00 & 0.65 \\
\hline CLEI & 21.69 & 16.62 & 7.96 & 16.87 & 0.63 & 1.09 & 0.18 & 92.83 \\
\hline HPC & 0.29 & 0.28 & 0.24 & 0.10 & -0.07 & 0.46 & 0.06 & 0.78 \\
\hline AQI & 1.23 & 1.20 & 1.18 & 0.29 & 0.38 & 0.50 & 0.52 & 2.54 \\
\hline
\end{tabular}

Table 2. Person pair-wise correlations.

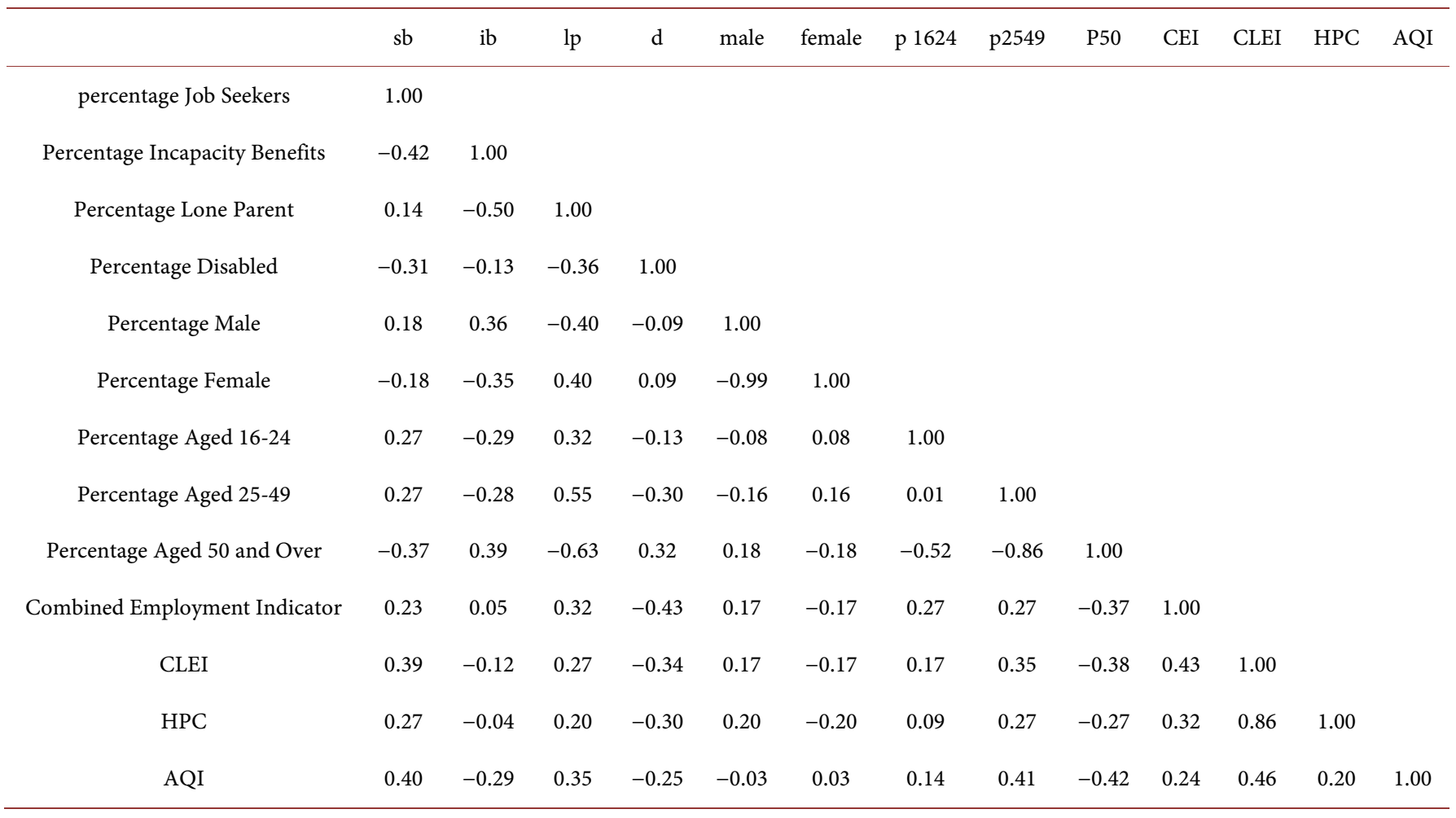


Table 3. Pearson pair-wise associations for air quality index and pollutants.

\begin{tabular}{cccccc}
\hline & $\mathrm{AQI}$ & $\mathrm{NO}_{2}$ & $\mathrm{PM} 10$ & $\mathrm{SO}_{2}$ & $\mathrm{C}_{6} \mathrm{H}_{6}$ \\
\hline $\mathrm{AQI}$ & 1.00 & & & \\
$\mathrm{NO}_{2}$ & 0.99 & 1.00 & & & \\
$\mathrm{PM}$ & 0.88 & 0.82 & 1.00 & & \\
$\mathrm{SO}_{2}$ & 0.36 & 0.28 & 0.18 & 1.00 & \\
$\mathrm{C}_{6} \mathrm{H}_{6}$ & 0.91 & 0.88 & 0.76 & 0.39 & 1.00 \\
\hline
\end{tabular}

Table 4. Summary of unadjusted bivariate linear regressions.

\begin{tabular}{ccccc}
\hline Independent Variable & $\begin{array}{c}\text { Regression } \\
\text { Coefficient }\end{array}$ & p-value & Adjusted R-Square & F-statistic p-value \\
\hline Total Persons & 0.00 & 0.00 & 0.12 & 0.00 \\
percentage Job Seekers & 0.00 & 0.00 & 0.07 & 0.00 \\
Percentage Incapacity Benefits & 0.00 & 0.00 & 0.00 & 0.00 \\
Percentage Lone Parent & 0.00 & 0.00 & 0.04 & 0.00 \\
Percentage Disabled & -0.01 & 0.00 & 0.09 & 0.00 \\
Percentage Male & 0.00 & 0.00 & 0.04 & 0.00 \\
Percentage Female & 0.00 & 0.00 & 0.04 & 0.00 \\
Percentage Aged 16 - 25 & 0.00 & 0.00 & 0.01 & 0.00 \\
Percentage Aged 25 - 49 & 0.00 & 0.00 & 0.07 & 0.00 \\
Percentage Aged 50 and Over & 0.00 & 0.00 & 0.07 & 0.00 \\
Employment Indicator & 0.48 & 0.00 & 0.10 & 0.00 \\
$\mathrm{CLEI}^{\text {AQI }}$ & 0.01 & 0.00 & 0.73 & 0.00 \\
$\mathrm{NO}_{2}$ & 0.07 & 0.00 & 0.04 & 0.00 \\
PM10 $_{\text {SO }}$ & 0.11 & 0.00 & 0.05 & 0.00 \\
$\mathrm{C}_{6} \mathrm{H}_{6}$ & 0.26 & 0.00 & 0.03 & 0.00 \\
\hline & -0.37 & 0.00 & 0.01 & 0.00 \\
\hline & 0.00 & 0.00 & \\
\hline
\end{tabular}

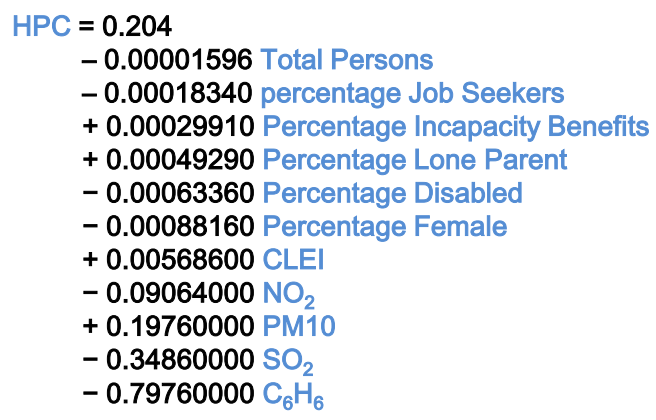

Figure 1. The constructed linear regression formula for HPC which explains 88.1 percent of variation within the dataset. 
Table 5. The developed multivariate linear regression model for HPC (Adjusted R-square: 0.8019; F-statistic p-value: 0).

\begin{tabular}{ccc}
\hline Independent Variable & Regression Coefficient & p-value \\
\hline Intercept & $2.04 \mathrm{E}-01$ & 0 \\
Total Persons & $-1.60 \mathrm{E}-05$ & 0 \\
percentage Job Seekers & $-1.83 \mathrm{E}-04$ & 0 \\
Percentage Incapacity Benefits & $2.99 \mathrm{E}-04$ & 0 \\
Percentage Lone Parent & $4.93 \mathrm{E}-04$ & 0 \\
Percentage Disabled & $-6.34 \mathrm{E}-04$ & 0 \\
Percentage Female & $-8.82 \mathrm{E}-04$ & 0 \\
$\mathrm{CLEI}$ & $5.69 \mathrm{E}-03$ & 0 \\
$\mathrm{NO}_{2}$ & $-9.06 \mathrm{E}-02$ & 0 \\
$\mathrm{PM}_{10}$ & $1.98 \mathrm{E}-01$ & 0 \\
$\mathrm{SO}_{2}$ & $-3.49 \mathrm{E}-01$ & 0 \\
$\mathrm{C}_{6} \mathrm{H}_{6}$ & $-7.98 \mathrm{E}-01$ & 0 \\
\hline
\end{tabular}

Table 6. Summary statistics for Leeds.

\begin{tabular}{|c|c|c|c|c|c|c|c|c|}
\hline & Mean & Median & Mode & Std. Dev. & Kurtosis & Skewness & Minimum & Maximum \\
\hline Total Persons & 136.32 & 102.50 & 65.00 & 92.90 & 1.20 & 1.19 & 5.00 & 545.00 \\
\hline percentage Job Seekers & 18.86 & 18.00 & 17.00 & 8.21 & 2.17 & 0.83 & 0.00 & 60.00 \\
\hline Percentage Incapacity Benefits & 49.05 & 50.00 & 50.00 & 8.77 & 2.16 & -0.20 & 0.00 & 82.00 \\
\hline Percentage Lone Parent & 11.01 & 10.50 & 0.00 & 8.11 & -0.81 & 0.25 & 0.00 & 32.00 \\
\hline Percentage Disabled & 8.30 & 7.00 & 6.00 & 5.78 & 7.35 & 1.84 & 0.00 & 50.00 \\
\hline Percentage Male & 50.43 & 50.00 & 50.00 & 7.95 & 4.46 & 0.55 & 14.00 & 100.00 \\
\hline Percentage Female & 49.59 & 50.00 & 50.00 & 7.94 & 4.51 & -0.54 & 0.00 & 86.00 \\
\hline Percentage Aged 16 - 25 & 13.58 & 13.00 & 13.00 & 6.47 & 4.02 & 0.83 & 0.00 & 50.00 \\
\hline Percentage Aged 25 - 50 & 49.04 & 50.00 & 50.00 & 9.42 & 1.39 & 0.12 & 17.00 & 100.00 \\
\hline Percentage Aged 50 and Over & 37.35 & 37.00 & 50.00 & 11.85 & -0.42 & 0.15 & 0.00 & 67.00 \\
\hline Combined Employment Indicator & 0.10 & 0.08 & 0.05 & 0.07 & 0.69 & 1.13 & 0.01 & 0.39 \\
\hline CLEI & 34.43 & 29.41 & 26.16 & 20.70 & -0.60 & 0.58 & 1.76 & 87.89 \\
\hline $\mathrm{HPC}$ & 0.32 & 0.30 & 0.24 & 0.11 & 0.21 & 0.71 & 0.07 & 0.67 \\
\hline AQI & 1.31 & 1.30 & 1.27 & 0.19 & 0.21 & 0.45 & 0.89 & 1.98 \\
\hline
\end{tabular}

Table 7. Person significant (p-value less than 0.05) pair-wise correlations for Leeds.

\begin{tabular}{|c|c|c|c|c|c|c|c|c|}
\hline & HPC & $\begin{array}{c}\text { Total } \\
\text { Persons }\end{array}$ & $\begin{array}{l}\text { Percentage Lone } \\
\text { Parent }\end{array}$ & $\begin{array}{c}\text { Percentage Aged } \\
25-49\end{array}$ & $\begin{array}{c}\text { Percentage Aged } 50 \\
\text { and Over }\end{array}$ & $\begin{array}{l}\text { Combined } \\
\text { Employment } \\
\text { Indicator }\end{array}$ & CLEI & AQI \\
\hline HPC & 1.00 & & & & & & & \\
\hline Total Persons & 0.53 & 1.00 & & & & & & \\
\hline $\begin{array}{l}\text { Percentage Lone } \\
\text { Parent }\end{array}$ & 0.46 & 0.64 & 1.00 & & & & & \\
\hline $\begin{array}{l}\text { Percentage Aged } \\
25-49\end{array}$ & 0.49 & 0.52 & 0.51 & 1.00 & & & & \\
\hline $\begin{array}{c}\text { Percentage Aged } 50 \\
\text { and Over }\end{array}$ & -0.56 & -0.63 & -0.59 & -0.84 & 1.00 & & & \\
\hline $\begin{array}{l}\text { Combined } \\
\text { Employment } \\
\text { Indicator }\end{array}$ & 0.47 & 0.95 & 0.63 & 0.46 & -0.54 & 1.00 & & \\
\hline CLEI & 0.95 & 0.60 & 0.54 & 0.50 & -0.60 & 0.55 & 1.00 & \\
\hline AQI & 0.34 & 0.51 & 0.34 & 0.42 & -0.48 & 0.43 & 0.48 & 1.00 \\
\hline
\end{tabular}




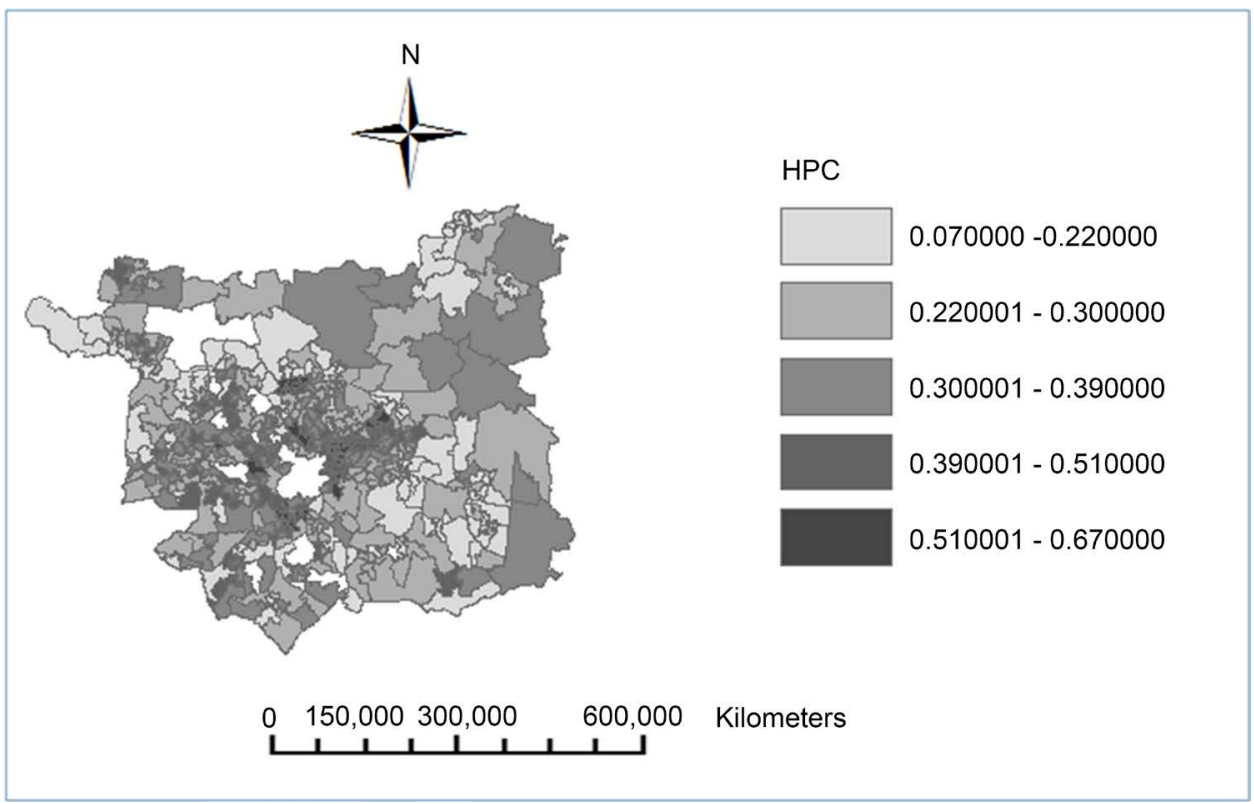

Figure 2. Leeds LSOA HPC values.

$\mathrm{HPC}=0.14-0.001$ Percentage Lone Parent +0.005 CLEI

Figure 3. The constructed linear regression formula for HPC in Leeds which explains 90 percent of variation within the dataset.

England and Wales. HPC in Leeds was strongly associated with percent of lone parent and CLEI whereas in England and Wales it was associated with the population size, percentage of job seekers, percentage of incapacity benefits, percentage of lone parent, percentage disabled, percentage of females, CLEI and four air pollutants (NO2, PM10, $\mathrm{SO} 2, \mathrm{C} 6 \mathrm{H} 6)$. Although the two study areas are not mutually exclusive, these differences could be attributed to differences in the demographics (Table 1 and Table 6). Furthermore, the persistence of percentage of lone parent and CLEI in both cases puts the deprived population deeper in poverty and require further attention [15].

The inclusion of individual air pollutants is justified by the way AQI is calculated and that its measurement reflects the highest pollutant at the time of measurement regardless of the other pollutants [16]. The pair-wise associations point to increased deprivation in areas near high vehicular traffic or stationary pollution sources like industrial facilities due to availability of cheaper housing near industrialised areas [17] which also contributes to lower health indicators for deprived population groups [15]. In spite of the governmental and advocate groups efforts to impose stricter air quality standards, the association between air pollutants measurements and deprivation persist and requires further attention by policy makers. Also, special attention is needed to regulate housing in industrialised areas.

The analysis for Leeds has the advantage of including data that are for one area and thus being consistent or harmonious whereas the data for England and Wales includes all cities and thus have more noise [18] [19]. 


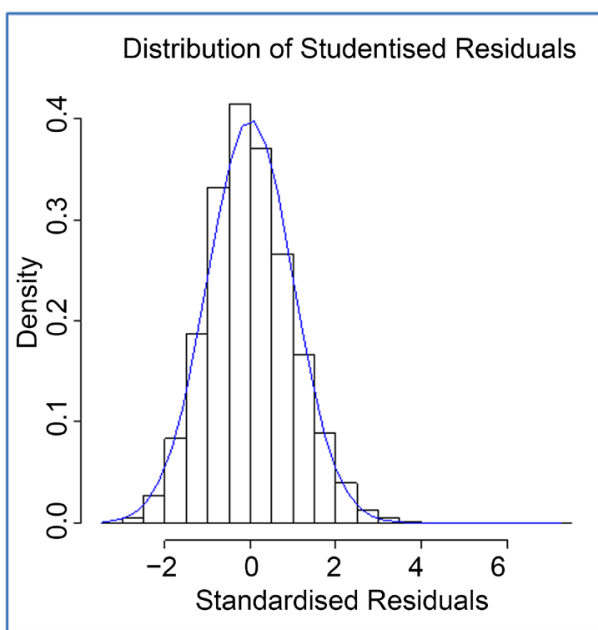

(a)

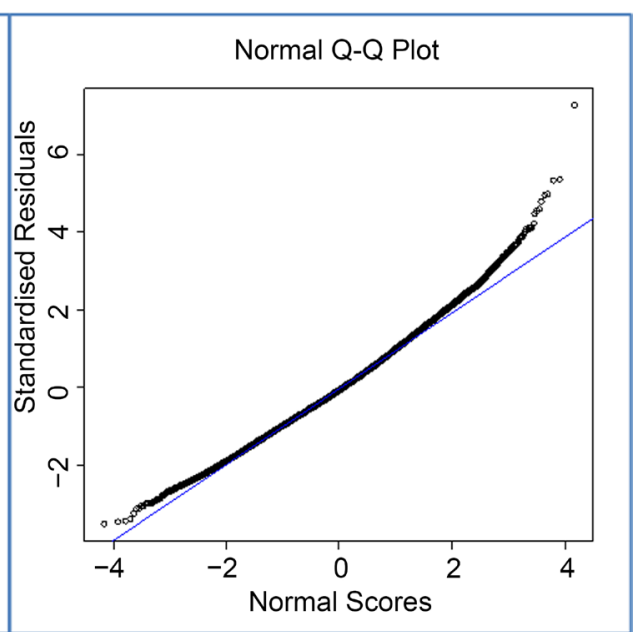

(b)

Figure 4. Residuals analysis of the linear regression for Leeds (HPC $=0.14-0.001$ Percentage Lone Parent $+0.005 \mathrm{CLEI}$ ). (a) presents the distribution of standardised residuals and (b) presents the Normal Q-Q Plot for the standardised residuals.

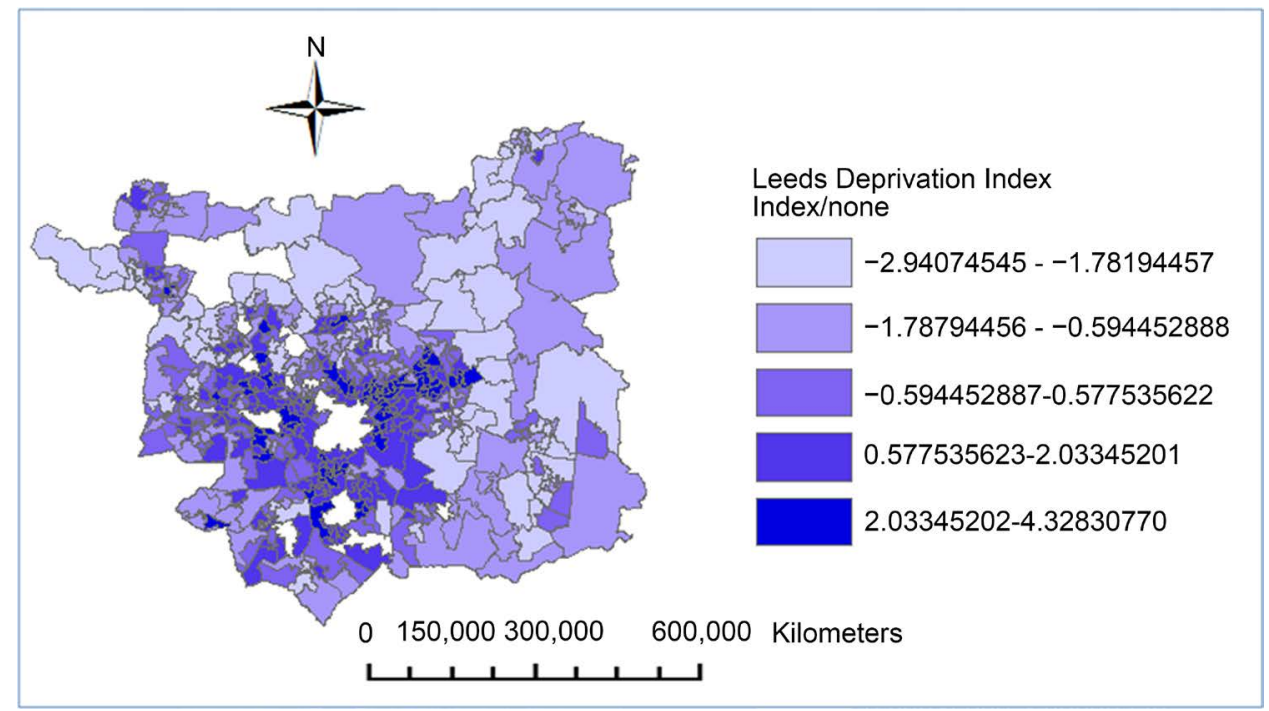

Figure 5. Geographic distribution of Leeds deprivation index which is the sum of standardised percentage of lone parent and standardised CLEI, at LSOA's level in 2001.

Leeds Data Mill (LDM) developed seven deprivation indices for Leeds: Income Deprivation (22.5\%), Employment Deprivation (22.5\%), Education and Skills Deprivation (13.5\%), Health and Disability Deprivation (13.5\%), Crime (9.3\%), Barriers to Housing and Services (9.3\%) and Living Environment Deprivation (9.3\%) [14]. These indices are not mutually exclusive; i.e.; they overlap with each other. This study's index overlaps with them too but has the advantage of being developed using mutually exclusive parameters because the pair-wise association between percentage of lone parent and CLEI was weak. Leeds City Council (LCC) provided deprivation index for Leeds based on a similar approach, which agrees geographically with the one developed herein except 
that it did not detect deprivation on some of the LSOAs at the peripheries of Leeds [20].

Poverty and Social Exclusion (PSE) in the United Kingdom research project funded by the Economic and Social Research Council states that "indicators that capture the relationship between poverty and housing must therefore give a good picture of the following main areas: the physical quality of housing, the degree of (over) crowdedness, suitability for the specific needs of the household; security of tenure and affordability of housing" [21]. Contrasting this definition to HPC it can be concluded that the indicator developed in this study for Leeds deprivation matches all the criteria set by PSE (2011).

The results of this study point to significant associations between income and housing conditions in both England and Wales and Leeds. This is the first study to develop a deprivation index for Leeds using mutually exclusive parameters and to contrast Leeds against England and Wales. Nevertheless, this study has the limitations of using fifteen year old data and not exhausting all other deprivation factors like health, education and crime. This could be the focus of future research.

\section{Conclusion}

This study presented a methodological approach to develop a deprivation index for Leeds, using multivariate linear regression and standardisation. The index is a proxy for poverty in Leeds. Leeds deprivation index was developed using standardised values for percentage of lone parent and Combined Living Environment Indicator because of their strong association to Housing in Poor Condition indicator. Despite the use of somewhat old data (fifteen years old), the study showed that certain factors like gender and age distribution were significant to England and Wales and not for Leeds. Furthermore, the study points to the need to further investigate the areas at the margins of Leeds where housing deprivation was higher than in other studies. The findings of the study also call both social and environmental policy makers to exert more efforts towards regulating housing near intensive air pollution sources.

\section{Acknowledgements}

This work used Census data obtained via MIMAS' CASWEB facility and GIS boundary data obtained via EDINA's UKBORDERS facility; services supported by ESRC and JISC. Census and Vital Statistics data for England and Wales, Scotland and Northern Ireland have been provided by the ONS, GROS and NISRA and the digital boundary data by OSGB and OSNI. These data are Crown copyright and are reproduced with permission of OPSI.

\section{References}

[1] Townsend, P. (1979) Poverty in the United Kingdom. Allen Lane and Penguin Books.

[2] Mack, J. (2016) Deprivation and Poverty. http://www.poverty.ac.uk/definitions-poverty/deprivation-and-poverty

[3] Bradshaw, J., Chzhen, Y. and Stephens, M. (2008) Housing: The Saving Grace in the British Welfare State? In: Fitzpatrick, S. and Stephens, M., Eds., Future of Social Housing, 7-25.

[4] Tunstall, R., et al. (2013) The Links between Housing and Poverty. 
https://www.jrf.org.uk/report/links-between-housing-and-poverty

[5] Thornton, D. (2013) The Story of Leeds. The History Press.

[6] McCann, M. (2010) How Leeds Changed the World. Armley Press.

[7] ONS. Neighbourhood Statistics (NeSS) 2016. http://www.neighbourhood.statistics.gov.uk/

[8] Data.gov.uk. Lower Layer Super Output Area (LSOA) boundaries. 2010. https://data.gov.uk/dataset/lower_layer_super_output_area_lsoa_boundaries

[9] Anderson, J., Delclos, G. and Rao, D.C. (2016) The Influence of Air Pollutants and Socioeconomic Status on Asthma in Texas. (In Press)

[10] ESRI, ArcMap 10.3.1. 2015, Redlands.

[11] Core, R. (2014) R: A Language and Environment for Statistical Computing.

[12] Anderson, F. (2016) Statistics by Example: Hands on Approach Using R and/or Excel. CreateSpace Independent Publishing Platform.

[13] Norman, G.R. and Streiner, D.L. (2008) Biostatistics: The Bare Essentials. PMPH-USA.

[14] LDM (2015) Indices of Deprivation for Leeds. http://leedsdatamill.org/dataset/indices-of-deprivation-for-leeds

[15] Anderson, F. and Al-Thani, N. (2016) Female Head, Food Stamps, Ethnicity and Air Pollution: Confounders or Causes of Heart Disease in Texas. Open Journal of Epidemiology. http://dx.doi.org/10.4236/ojepi.2016.62015

[16] DEFRA (2013) Daily Air Quality Index. https://uk-air.defra.gov.uk/air-pollution/daqi

[17] Mohai, P., Pellow, D. and Roberts, J.T. (2009) Environmental Justice. Annual Review of Environment \& Resources, 34, 405-430.

http://dx.doi.org/10.1146/annurev-environ-082508-094348

[18] Anderson, F., et al. (2015) Age, Race and Gender Spatiotemporal Disparities of COPD Emergency Room Visits in Houston, Texas. Occupational Diseases and Environmental Medicine, 3, 1-9. http://dx.doi.org/10.4236/odem.2015.31001

[19] Baxter, M. (1983) Estimation and Inference in Spatial Interaction Models. Progress in Human Geography.

[20] LCC (2011) Deprivation. http://democracy.leeds.gov.uk/documents/s62979/appendix

[21] PSE (2011) Poverty and Social Exclusion in the UK. http://www.poverty.ac.uk/system/files/attachments/WP\%20Methods\%20No.6\%20-\%20Ho using\%20Living\%20Environment\%20Indicators\%20(Besemer,\%20Bramley).pdf 
Submit or recommend next manuscript to SCIRP and we will provide best service for you:

Accepting pre-submission inquiries through Email, Facebook, LinkedIn, Twitter, etc. A wide selection of journals (inclusive of 9 subjects, more than 200 journals)

Providing 24-hour high-quality service

User-friendly online submission system

Fair and swift peer-review system

Efficient typesetting and proofreading procedure

Display of the result of downloads and visits, as well as the number of cited articles

Maximum dissemination of your research work

Submit your manuscript at: http://papersubmission.scirp.org/

Or contact jss@scirp.org 